\title{
RANCANG BANGUN APLIKASI PEMBELAJARAN LARUTAN ELEKTROLIT DAN NON-ELEKTROLIT DARI KIMIA DASAR BERBASIS ANDROID
}

\author{
DESIGN AND DEVELOPMENT OF ELECTROLYTE AND NON-ELECTROLYTE \\ SOLUTIONS LEARNING APPLICATIONS FROM ANDROID BASED \\ ON BASIC CHEMISTRY
}

\author{
Luluk Elvitari ${ }^{1}$ \\ Universitas Abdurrab \\ Indonesia $^{1}$ \\ email: \\ luluk@univrab.ac.id
}

\section{Siti Nurjannah ${ }^{2}$ Universitas Abdurrab Indonesia $^{2}$}

IJI Publication p-ISSN: 2774-1907 e-ISSN: $2774-1915$ Vol. 1, No. 3, pp. 228237, Juli 2021

\footnotetext{
Unit Publikasi Ilmiah Intelektual Madani Indonesia
}

Abstrak: Penerapan media pembelajaran larutan elektrolit dan non elektrolit yang merupakan media pembelajaran yang memanfaatkan smartphone untuk memberikan pengalaman belajar yang berbeda bagi siswa berbasis Android, berupa multimedia yang bersifat edukatif dan bermanfaat untuk meningkatkan kemampuan berpikir. Sehingga dapat membantu siswa dalam mempelajari dan memahami materi pada mata pelajaran kimia salah satunya materi tentang larutan. Multimedia memiliki peranan yang sangat penting dalam berbagai bidang seperti : pendidikan, hiburan, dll. Khususnya dalam bidang pendidikan, proses pembelajaran siswa saat ini lebih ditekankan pada pendidikan visual yang akan lebih mudah dipahami dan terlihat menarik dengan tambahan gambar dan suara dalam bentuk multimedia. Tujuan dari penelitian ini adalah agar siswa tertarik dan mudah memahami dalam mempelajari materi larutan pada mata pelajaran kimia. Penerapan media pembelajaran larutan elektrolit dan nonelektrolit diuji menggunakan metode pengujian black box dan angket yang dibagikan kepada beberapa siswa SMA, hasil penelitian ini membuktikan bahwa penerapan elektrolit dan nonelektrolit berbasis android media pembelajaran solusi dapat memberikan motivasi belajar siswa dan juga dapat digunakan sebagai bantuan guru dalam memberikan penjelasan materi dan praktikum tentang solusi pembelajaran, dalam berbagai bentuk.

Kata Kunci: Larutan Elektrolit dan Non Elektrolit, Kimia, Android, Aplikasi Pembelajaran.

Abstract: The application of learning media for electrolyte and non-electrolyte solutions which is a learning medium that utilizes smartphones to provide a different learning experience for Androidbased students, in the form of multimedia, which is educational and useful for improving thinking skills. So that it can help students in studying and understanding the material in chemistry subjects, one of which is material about solutions. Multimedia has a very important role in various fields such as: education, entertainment, etc. Especially in the field of education, the student learning process at this time is more emphasis on visual education which will be easier to understand and look attractive with the addition of images and sounds in the form of multimedia. The purpose of this study was to make students interested and easy to understand in studying solution material in chemistry subjects. The application of learning media for electrolyte and nonelectrolyte solutions was tested using the black box testing method and questionnaires, which were distributed to several high school students, the results of this study prove that the application of Android-based electrolyte and non-electrolyte solution learning media can provide student learning motivation and also can be used as a teacher's aid in providing an explanation of the material and practicum on learning solutions, in different forms.

Keywords: Electrolyte and Non-Electrolyte Solutions, Chemistry, Android, Learning Applications.

\section{PENDAHULUAN}

Perkembangan teknologi yang sangat pesat dibidang pendidikan membuat pengaruh yang sangat baik dalam majunya dunia pendidikan. Sehingga melahirkan bermacam-macam media pembelajaran baru yang berbau teknologi. Ini berdampak positif bagi dunia pendidikan, karena dengan adanya media-media pembelajaran yang semakin canggih akan sangat berguna dan membantu siswa dalam belajar.

\section{Kimia}

merupakan

ilmu

yang mempelajari mengenai larutan, komposisi, struktur, dan sifat zat atau materi dari skala atom hingga molekul serta perubahan atau transformasi serta interaksi mereka untuk membentuk materi yang ditemukan seharihari. Pada pelajaran kimia terdapat juga materi larutan elektrolit dan non-elektrolit. Larutan elektrolit adalah larutan yang dapat menghantarkan arus listrik sedangkan nonelektrolit adalah larutan yang tidak dapat 
menghantarkan arus listrik. Dalam ilmu kimia juga mempelajari pemahaman sifat dan interaksi atom individu dengan tujuan untuk menerapkan pengetahuan tersebut pada tingkat makroskopik, atau pernyataan sifat ukuran yang dapat dilihat dengan mata. (Dwinata, Efendi \& Yudha, 2016).

Pelajaran kimia merupakan salah satu mata pelajaran di sekolah menengah atas yang masih dianggap sulit oleh sebagian siswa, materi di dalam mata pelajaran kimia mencakup hafalan, hitungan, dan pratikum. Sehingga dibutuhkan sebuah media pembelajaran yang mudah untuk dipahami oleh siswa. Di era digital saat ini smartphone dapat dimanfaatkan untuk mempermudah proses pembelajaran siswa khususnya pada mata pelajaran kimia pada pokok pembahasan larutan elektrolit dan nonelektrolit. Materi larutan ini merupakan salah satu materi yang sulit diantara materi yang sulit lain nya karena pada sub materi ini terdapat pratikum dan rumus yang akan lebih mudah dipahami oleh siswa jika dalam bentuk animasi. Media yang akan dirancang bangun berbasis android ini menggunakan aplikasi Adobe Flash CS6, dalam tampilan/bentuk suara, gambar, animasi dan elemen-elemen digital lainnya. Sehingga dapat membantu siswa dalam mempelajari dan memahami materi dalam mata pelajaran kimia.

\section{METODE}

Pada tahapan merupakan langkah kerja yang dilakukan dalam penelitian ini :

Gambar 1

Langkah Kerja

IDENTIFIKASI MASALAH

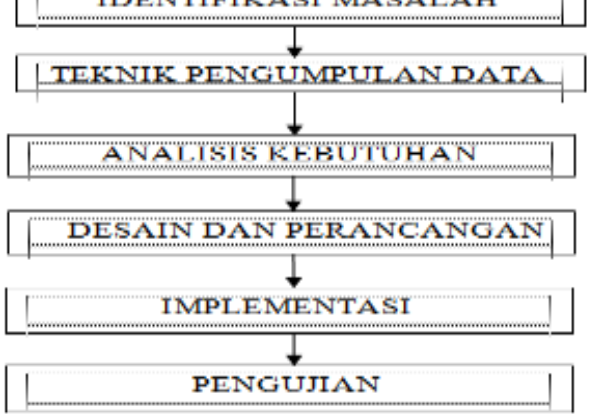

\section{Identifikasi Masalah}

Tahap ini merupakan tahap awal pada penyusunan penelitian. Hasil dari identifikasi inilah akan muncul latar belakang dalam melakukan perumusan masalah yang akan menjadi objek penelitian masalah yang akan di identifikasi adalah merancang bagun aplikasi pembelajaran larutan elektrolit dan non-elektrolit berbasis android supaya siswa bisa mudah paham dan mengerti belajar kimia contoh materi tentang larutan elektrolit dan non-elektrolit.

2. Teknik Pengumpulan Data

Untuk mendapatkan data yang mendukung tentang penelitian ini. Maka penulisan menggunakan beberapa metode yaitu:

a. Wawancara (interview)

Wawancara merupakan salah satu teknik pengumpulan data dengan cara melakukan tanya jawab tentang masalahmasalah yang berhubungan dengan penelitian penulis kepada pihak-pihak yang bersangkutan dengan penelitian penulis, baik dari siswa serta guru-guru yang mengajar pelajaran kimia, yang terdapat di sekolah menegah atas di pekanbaru, salah satu nya di SMA Negeri 05 Tapung Kabupaten Kampar Desa karya indah Jalan Karosin KM. 4,5 Garuda sakti.

b. Observasi

Untuk mengetahui tentang materi dan pratikum larutan elektrolit dan non-elektrolit maka penulis melakukan observasi di SMA Negeri 05 Tapung Kabupaten Kampar Desa karya indah Jalan Karosin KM. 4,5 Garuda sakti.

c. Studi Pustaka

Yaitu pengumpulan data dengan menggunakan buku dan jurnal sebagai bahan acuan referensi yang berhubungan dengan penelitan penulis untuk menyempurnakan tugas akhir sehingga hasil nya sesuai dengan yang diharapkan. 


\section{d. Dokumentasi}

Pengambilan gambar atau foto untuk melengkapi bahan penelitian.

e. Analisis Kebutuhan

Setelah data yang di perlukan untuk penelitian terkumpul maka langkah selanjutnya adalah melakukan analisis kebutuhan. Yang dilakukan untuk mengetahui apa saja yang di butuhkan dalam merancang suatu aplikasi pembelajaran larutan elektrolit dan non-elektrolit dari kimia dasar. Sehingga aplikasi yang di rancang dapat menciptakan media pembelajaran yang menarik dan mudah di pahami oleh siswa.

Adapun sistem pendukung dalam penelitian yang di gunakan untuk menyusun tugas akhir ini terdiri darim (1) Hardware, Yaitu : Processor, Installed memory (RAM) berkapasitas 2 GB, Windows 7 Home Premium, (2) Software, Yaitu: Sistem Operasi Microsoft Windows 7, Microsoft Office Word 2007, Adobe Flash CS6.

f. Konsep Desain dan Perancangan

Konsep desain dan rancangan di lakukan sebelum terbentuknya suatu aplikasi. Hal ini di lakukan agar aplikasi nanti nya sesuai yang di rencanakan dan agar aplikasi nya berjalan semestin nya sesuai rancangan awal.

\section{HASIL DAN DISKUSI}

Pada tahapan ini pembuatan flowchart system yang dilakukan setelah tahapan desain dan perancangan. flowchart system perlu dilakukan untuk menjelaskan aliran sistem dari aplikasi pembelajaran larutan elektrolit dan non-elektrolit dari kimia dasar berbasis android, disamping itu juga memberikan gambaran tentang informasi apa saja yang dapat dihasilkan oleh sistem yang dirancang tersebut. Untuk lebih rinci, selanjutnya akan dijelaskan masing-masing alur dari flowchart system yang berjalan pada aplikasi.
Gambar 2

Flowchart Aplikasi Larutan

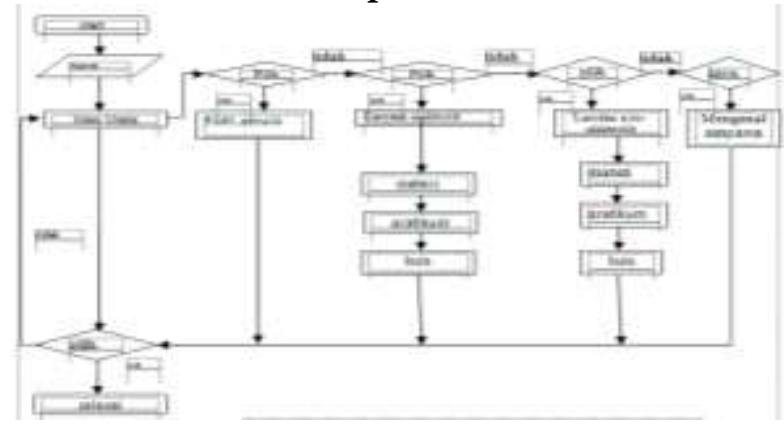

\section{Implementasi dan Pembahasan}

Pada bagian ini membahas tentang pembuatan aplikasi media pembelajaran larutan elektrolit dan non-elektrolit yang akan di gunakan untuk siswa SMA, membuat komponen media pembelajaran materi larutan elektrolit dan non-elektrolit dan membuat tampilan menu awal. Pembuatan media pembelajaran larutan mengunakan aplikasi Adobe Flash CS6 untuk membuat komponen berbasis android

\section{Komponen Pendukung}

Dalam pembuatan aplikasi media pembelajaran larutan elektrolit dan nonelektrolit dari kimia dasar, penulis melakukan pengumpulan bahan atau properti, mulai dari pembuatan komponen komputer yang tampilan menu pada aplikasi menggunakan aplikasi Adobe Flash CS6.

Untuk pembuatan aplikasi, langkah pertama yaitu membuka aplikasi Adobe Flash CS6, kemudian pilih Air. For Android kemudian muncul tampilan kerja lalu pilih Action Script 3.0 supaya hasilnya berbasis android.

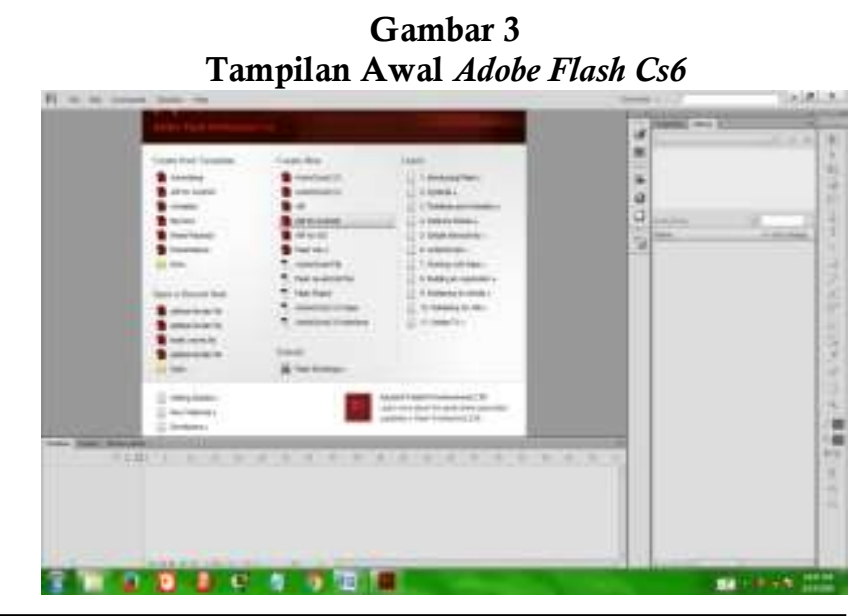




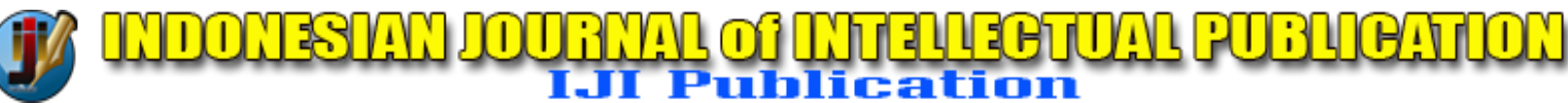

p-ISSN: 2774-1907; e-ISSN: 2774-1915; Vol.1, No.3, Juli 2021

Selanjutnya pembuatan tampilan awal yang berlatar belakang gambar dan loading yang di buat menggunakan fill color menggunakan gambar yang sudah di siapkan dan pilih rectangle tool untuk membuat objek gambar setelah itu di seleksi bagian gambar nya menggunakan selection tool. Dan supaya gambar terlihat bergerak menggunakan Create Classic Tween pada layer 2. Sehingga hasilnya seperti gambar di bawah ini :

\section{Gambar 4}

Tampilan Halaman Intro

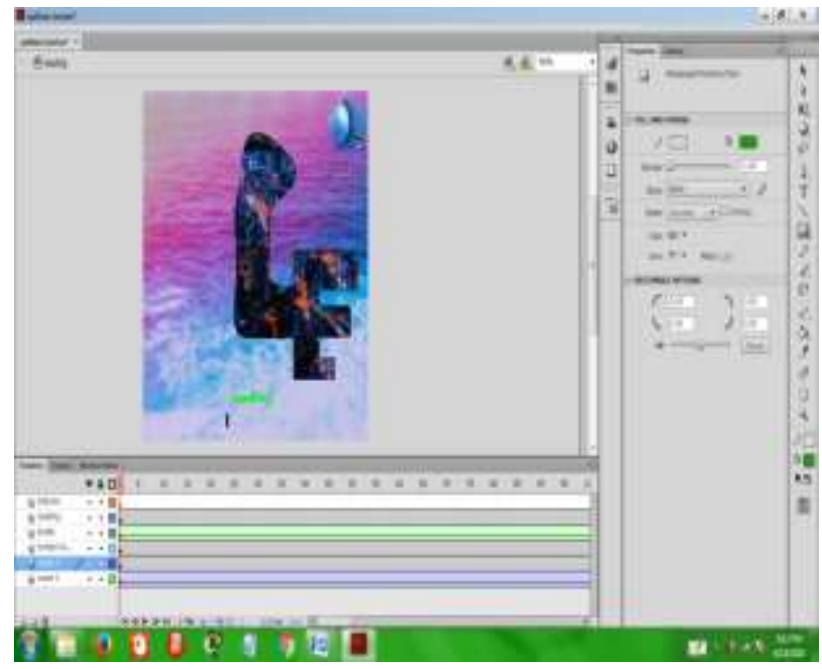

Selanjutnya untuk tampilan awal aplikasi yang menampilkan beberapa menu. Yang dibuat menggunakan rectangle primitive tool dan untuk membuat gambar animasinya menggunakan brush tool dan setiap menu harus dijadikan button supaya button nya bisa diklik untuk menampilkan menu berikutnya. Setiap tombol button di masukan coding dengan mengklik kanan pilih pada mouse lalu pilih action selanjutnya pilih code snippets masuk kan action, untuk memasukan coding pada button dalam satu scane tetapi beda frame maka action script nya seperti berikut:

Name_button.addEventListener(MouseEvent.CLICK,fl_C lickToGoToAndStop_AtFrame_91);

function

fl_ClickToGoToAndStopAtFrame_91(event:MouseEvent) :void \{

gotoAndStop (no frame); $\}$

Untuk action script beda scene dan frame, maka coding nya seperti berikut:

Name button. add

EventListener(MouseEvent.CLICK,_fl_ClickToGoToScene _13);

function
fl_ClickToGoToScene_13(event:MouseEvent):void MovieClip(this.root).gotoAndPlay(no frame, "Scene no scene"); \}

Dan untuk Action script keluar aplikasi maka coding nya sebagai berikut.

keluarapk.addEventListener(MouseEvent.CLICK, klik_keluar);

function klik_keluar(e:MouseEvent):void \{

NativeApplication.nativeApplication.exit(0); \}

Gambar 5

Tampilan Action Script

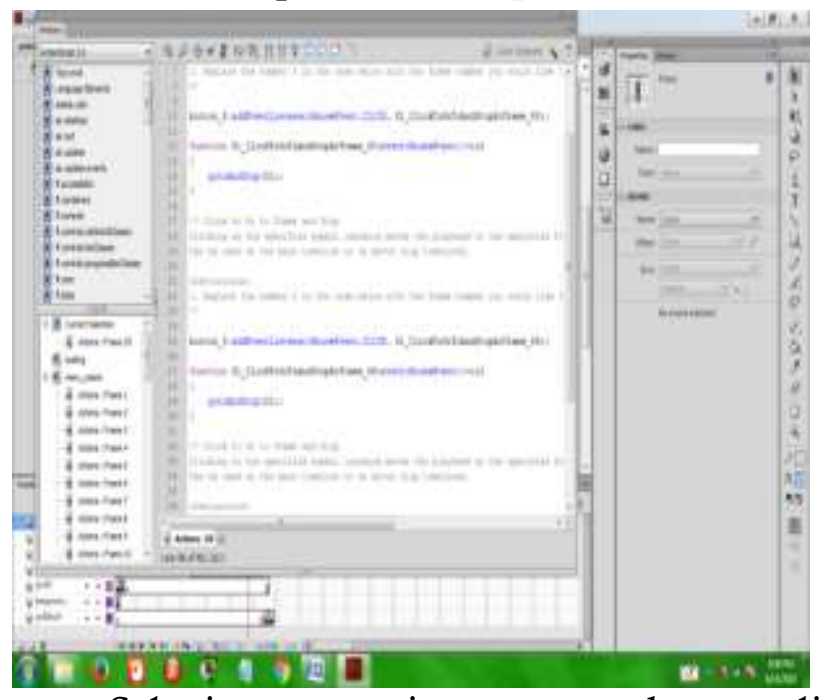

Selanjutnya setiap menu harus di jadikan button langkah pertama klik kanan mouse cari dan klik convert to symbol lalu pilih button supaya menu bisa diklik untuk menampilkan menu berikutnya jika untuk membuat animasi bergerak maka pilih movie clip seperti gambar di bawah ini :

\section{Gambar 6}

Tampilan Pembuatan Menu

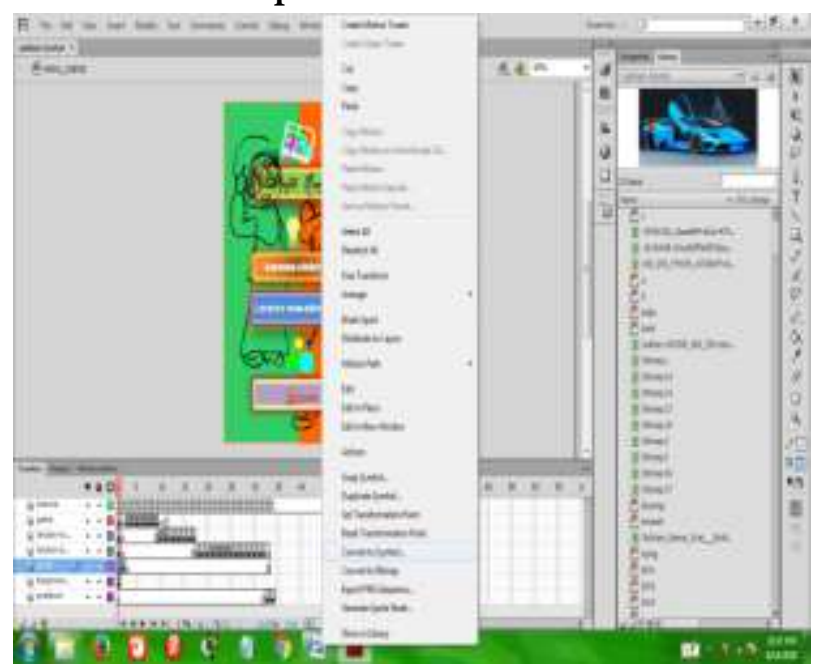

Dan tampilan menu aplikasi media pembelajaran larutan elektrolit dan nonelektrolit seperti gambar di bawah ini : 


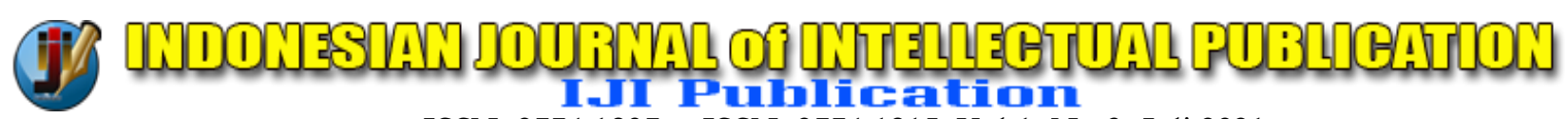

p-ISSN: 2774-1907; e-ISSN: 2774-1915; Vol.1, No.3, Juli 2021

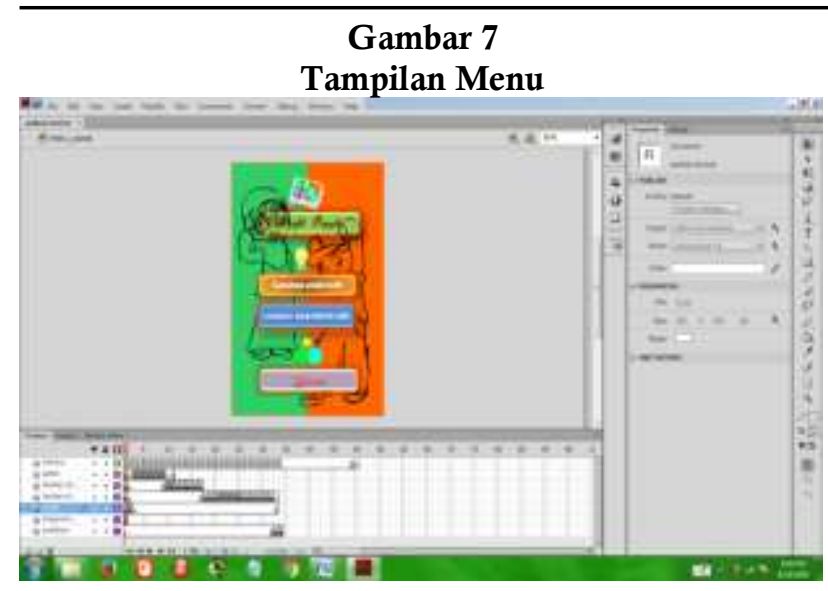

Pada pilihan menu terdapat menu Game yang menampilkan permainan tebak warna menggunakan Ovall tool untuk membuat beberapa pilihan warna seperti gambar di bawah ini :

\section{Gambar 8}

Tampilan Permainan Tebak Warna

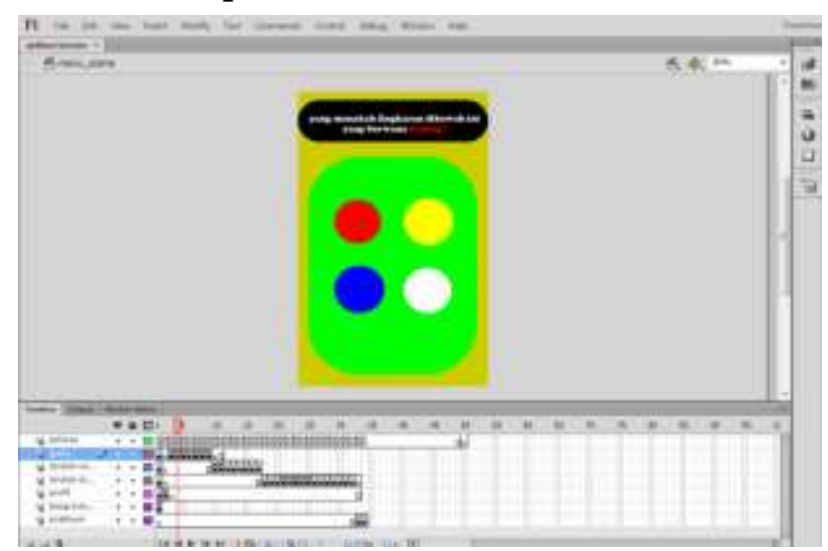

Berikut memasukan materi untuk pembelajar larutan non-elektrolit tampilan sama untuk larutan elektrolit hanya saja beda materi dan pratikum yang di gunakan tampilannya dapat dilihat pada gambar di bawah ini :

\section{Gambar 9}

Tampilan Materi

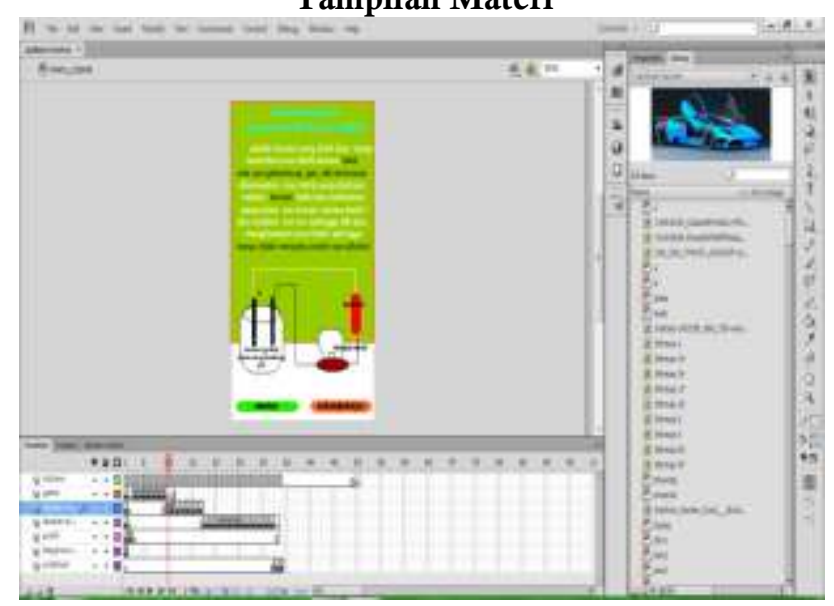

\section{Hasil program}

Penulis akan membahas hasil dari aplikasi pembelajaran larutan elektrolit dan non-elektrolit berbasis android yang akan berisikan beberapa menu dan halaman diantaranya adalah sebagai berikut:

a) Tampilan aplikasi di wallpaper android, tampilan ini untuk melihat aplikasi yang sudah di instal pada handphone kita, tampilannya dapat dilihat sebagai berikut:

\section{Gambar 10}

Tampilan Aplikasi Di Wallpaper

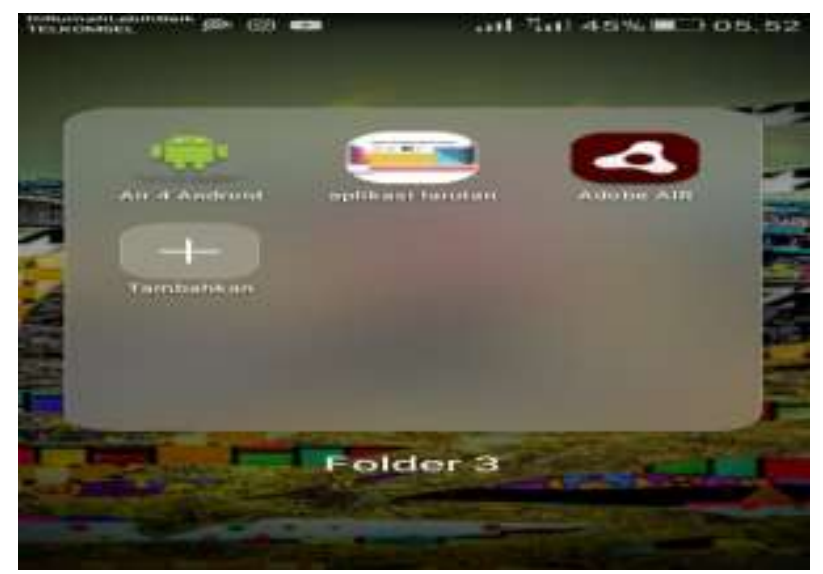

b) Halaman intro adalah tampilan awal pada pembukaan aplikasi sebelum ke menu utama tampilannya dapat dilihat sebagai berikut :

\section{Gambar 11}

Tampilan Halaman Intro

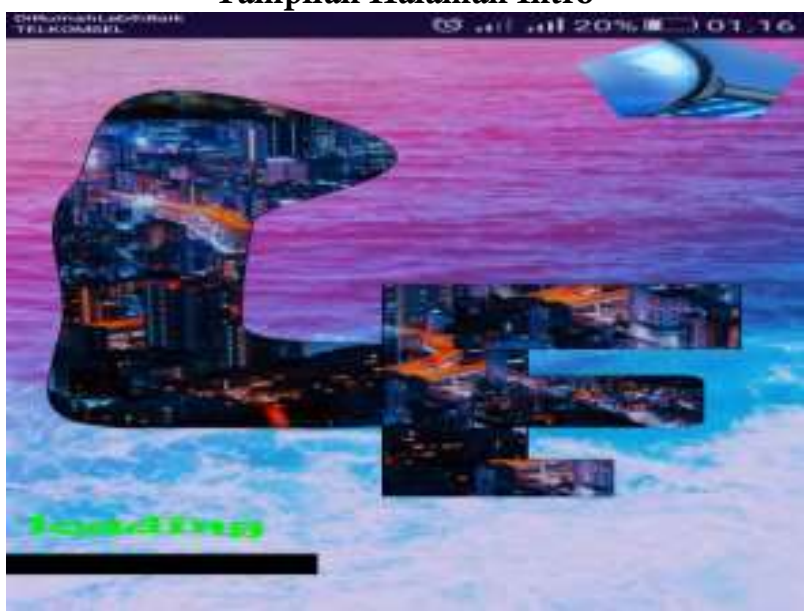

c) Tampilan halaman menu terdapat beberapa pilihan button menu di antaranya menu biodata, menu larutan elektrolit, menu larutan non-elektrolit dan menu game tampilan menu utama dapat dilihat sebagai berikut: 
p-ISSN: 2774-1907; e-ISSN: 2774-1915; Vol.1, No.3, Juli 2021

Gambar 12

Tampilan Halaman Home Menu

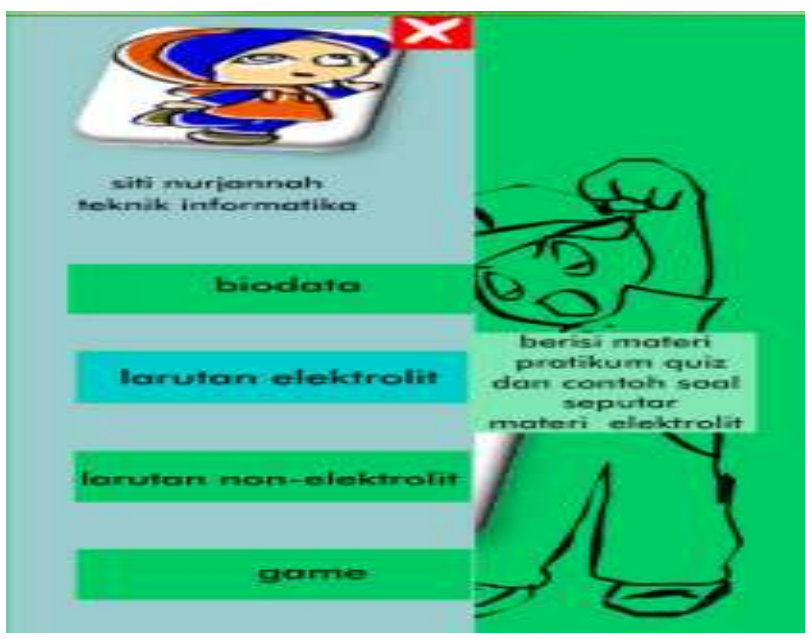

Gambar 13

Tampilan Halaman Menu Utama

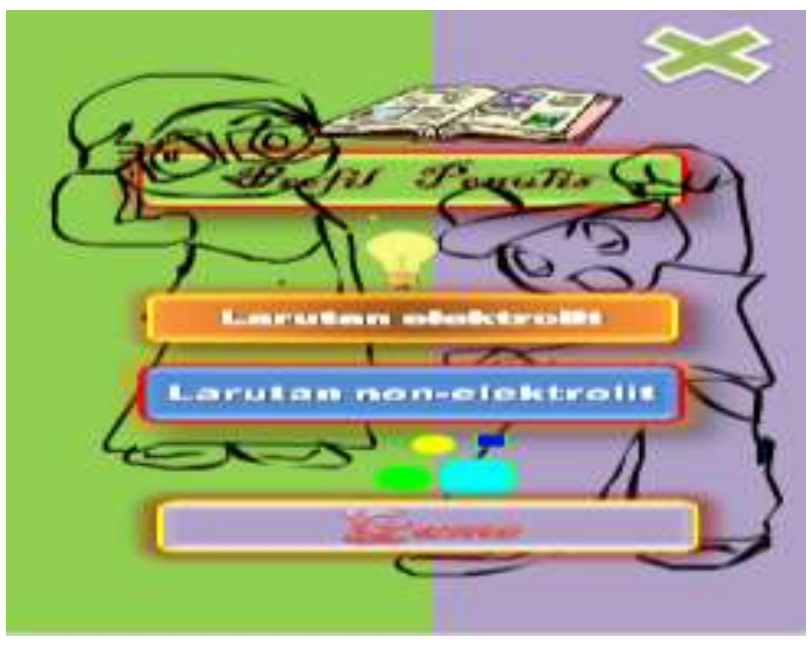

d) Pada tampilan halaman menu biodata berisi profil penulis dapat dilihat sebagai berikut :

Gambar 14

Tampilan Halaman Menu Biodata

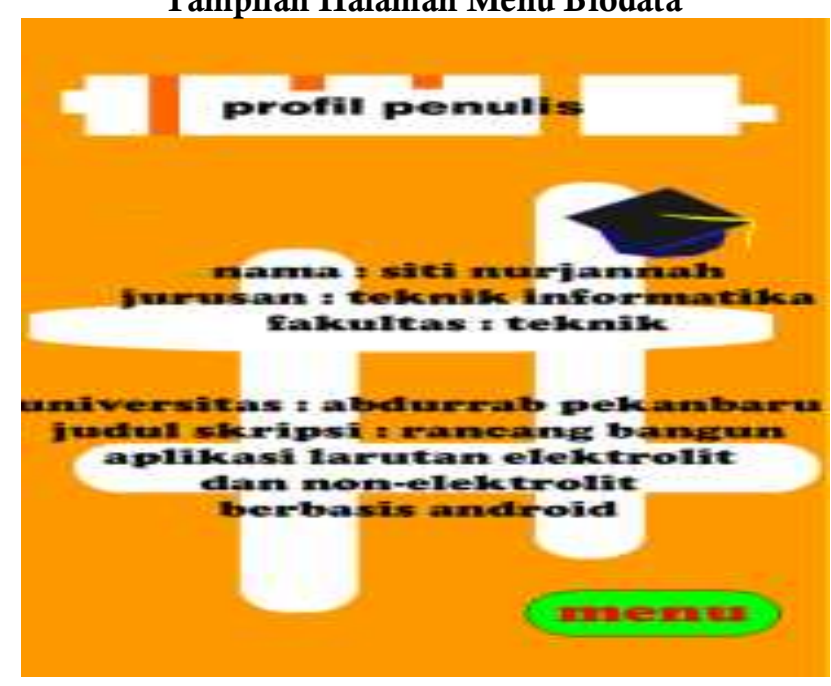

e) Tampilan halaman menu larutan elektrolit berisi tentang materi larutan elektrolit kuat dan elektrolit lemah, pratikum, quis. Dan pada halaman uji coba daya hantar listrik, dimana pada menu ini terdapat beberapa jenis larutan yang nantinya di uji coba apakah larutan tersebut elektrolit atau nonelektrolit dalam bentuk animasi dapat dilihat sebagai berikut :

\section{Gambar 15}

Halaman Menu Larutan Elektrolit

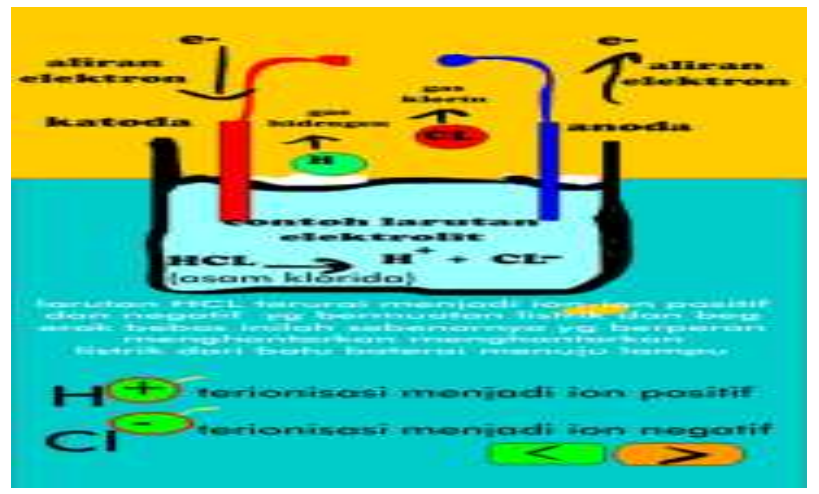

Gambar 16

Tampilan Halaman Pratikum Larutan Elektrolit

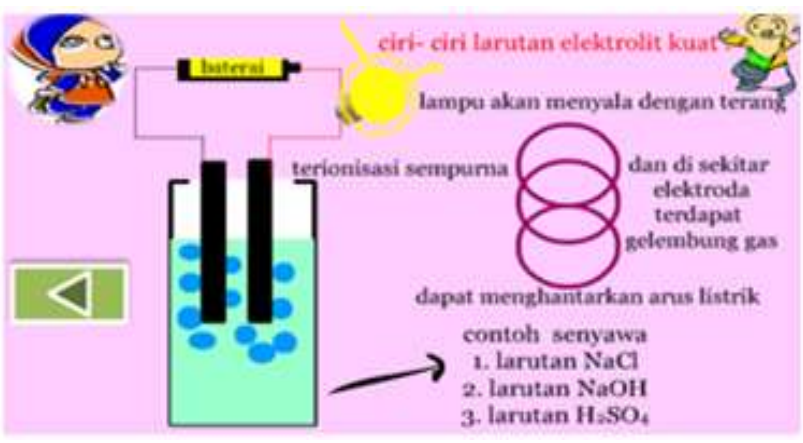

Gambar 17

Tampilan Halaman Uji Coba Daya Hantar Listrik

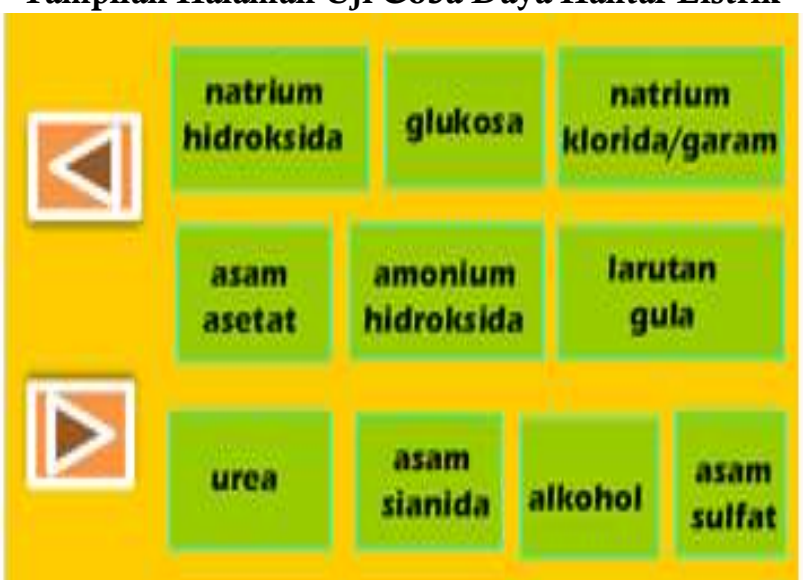

f) Tampilan halaman menu larutan nonelektrolit pada halaman ini berisi tentang materi, pratikum dan quis yang membahas tentang larutan non-elektrolit tampilannya dapat dilihat sebagai berikut : 


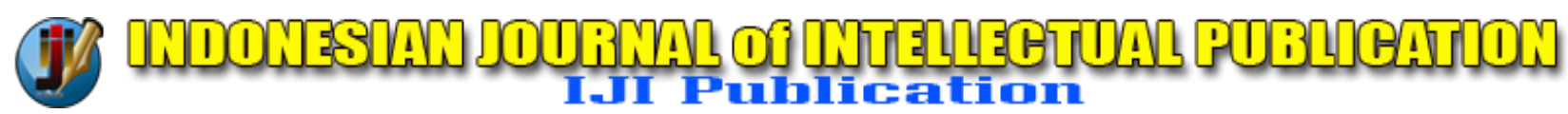

p-ISSN: 2774-1907; e-ISSN: 2774-1915; Vol.1, No.3, Juli 2021

\section{Gambar 18}

Tampilan Halaman Larutan Non-Elektrolit

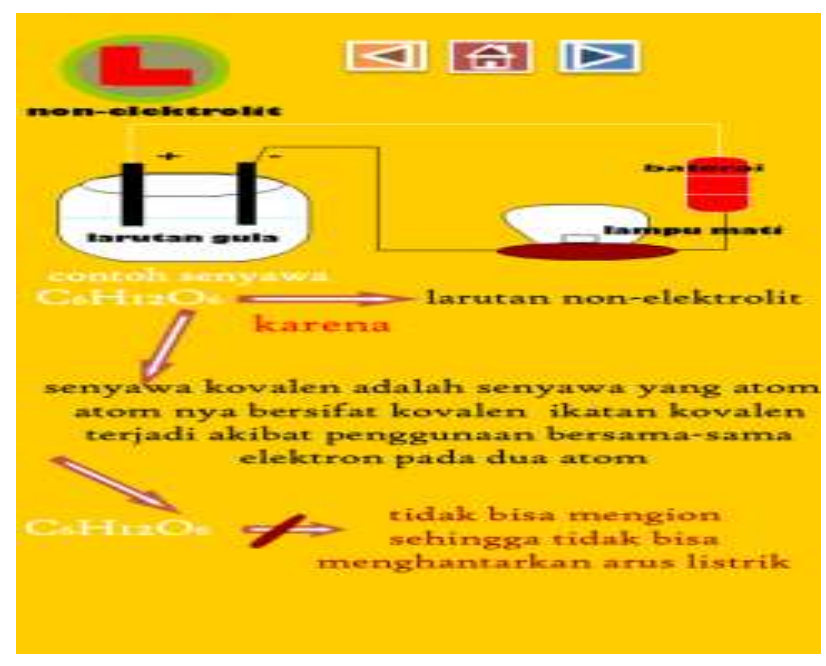

Pada menu ini terdapat materi yang membahas senyawa kimia dari larutan nonelektrolit beserta animasinya.

\section{Gambar 19}

Tampilan Halaman Quis Larutan Non-Elektrolit

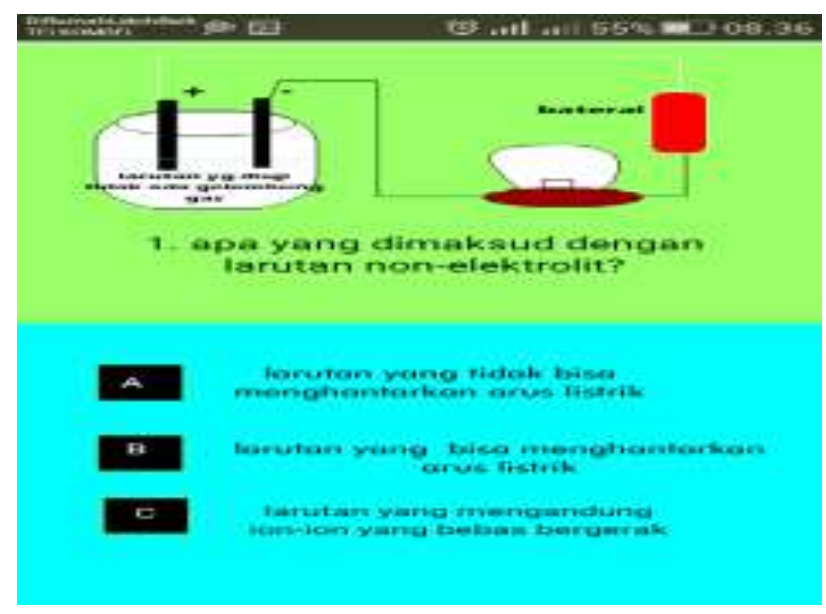

Pada menu ini terdapat beberapa soal yang membahas tentang materi-materi larutan non-elektrolit.

Gambar 20

Tampilan Halaman Pratikum Larutan Non-Elektrolit

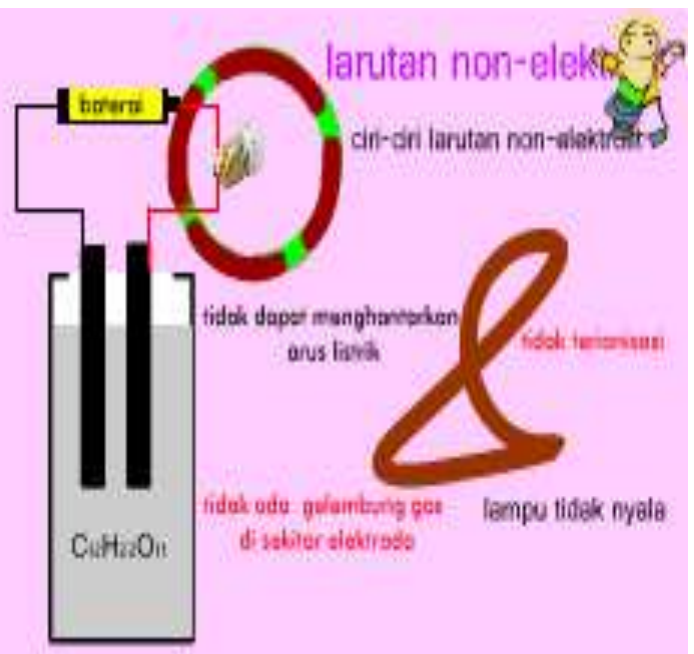

g) Tampilan halaman menu game pada menu ini berisi permainan tebak nama senyawa kimia, ketika halaman ini muncul maka halaman pertama pada menu ini adalah gambar tabel periodik, tebel ini berfungsi untuk memudahkan siswa menjawab game tersebut. Pilihan yang harus di pilih pada game ini adalah, jika salah maka kita akan diberi pilihan keluar atau kembali bermain. Dapat dilihat sebagai berikut :

Gambar 21

Tampilan Gambar Tabel Periodik

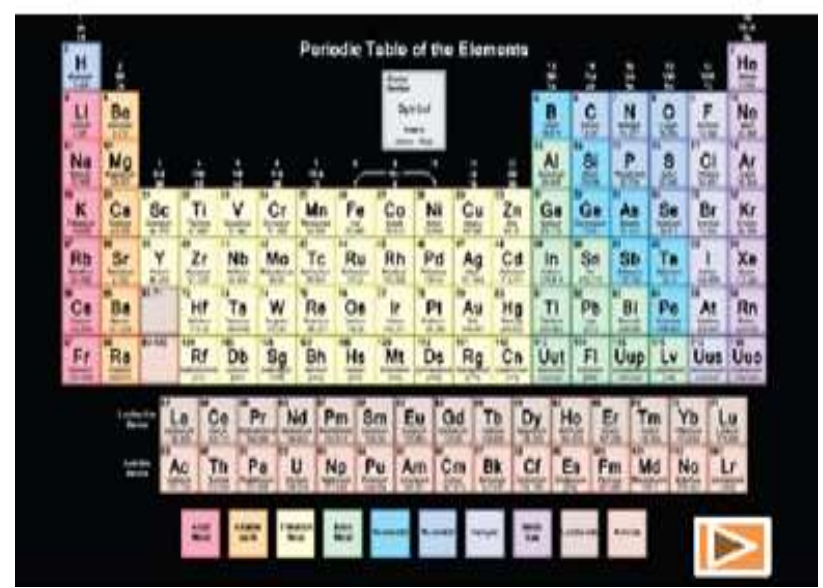

Gambar 22

Tampilan Halaman Menu Game

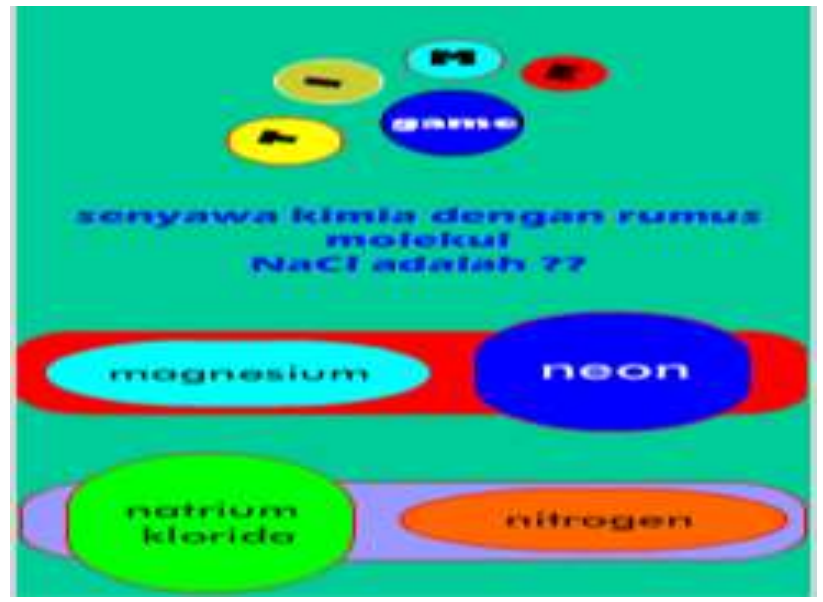

Pada game ini berisi pertanyaan tentang beberapa nama senyawa kimia jika jawaban benar maka akan ke tampilan berikutnya.

\section{Pengujian}

Pengujian aplikasi media pembelajaran larutan elektrolit dan non-elektrolit menggunakan black box atau black box testing yang merupakan jenis testing yang lebih berkonsentrasi terhadap isi dari perangkat 
lunak yang tidak diketahui kinerja internalnya. Sehingga para tester memandang perangkat lunak seperti layaknya sebuah "kotak hitam" yang tidak penting dilihat dari isinya, tapi cukup dikenali proses testing dibagian luar (Adami \& Budi hatanti, 2016). Black box digunakan karena untuk mengetahui apakah fungsi-fungsi, masukan, dan keluaran dari media sesuai dengan spesifikasi yang dibutuhkan.

Tabel 1

Pengujian Black box "Halaman Menu"

\begin{tabular}{|c|c|c|c|}
\hline \\
\hline No & Pengujian & $\begin{array}{l}\text { Hasil yang } \\
\text { diharapkan }\end{array}$ & $\begin{array}{l}\text { Hasil yang } \\
\text { didapatkan }\end{array}$ \\
\hline 1. & $\begin{array}{l}\text { Submenu } \\
\text { profil penulis }\end{array}$ & $\begin{array}{l}\text { Masuk ke } \\
\text { halaman profil } \\
\text { penulis }\end{array}$ & Lengkap \\
\hline 2. & $\begin{array}{l}\text { Submenu } \\
\text { larutan } \\
\text { elektrolit }\end{array}$ & $\begin{array}{l}\text { Masuk ke } \\
\text { halaman } \\
\text { larutan } \\
\text { elektrolit }\end{array}$ & Lengkap \\
\hline 3. & $\begin{array}{l}\text { Submenu } \\
\text { larutan non- } \\
\text { elektrolit }\end{array}$ & $\begin{array}{l}\text { Masuk ke } \\
\text { halaman } \\
\text { larutan non- } \\
\text { elektrolit }\end{array}$ & Lengkap \\
\hline 4. & $\begin{array}{l}\text { Submenu } \\
\text { game }\end{array}$ & $\begin{array}{l}\text { Masuk ke } \\
\text { halaman game } \\
\text { tebak warna }\end{array}$ & Lengkap \\
\hline
\end{tabular}

Dilihat dari tabel 4 hasil uji black box berupa pengujian submenu profil penulis submenu larutan elektrolit, submenu larutan non-elektrolit, submenu game. Dalam pengujian ini tombol, design, tampilan background dan lainnya diuji apakah sudah memenuhi atau tidak.

\section{Hasil Penilaian Angket/Kuesioner}

Pengujian dalam aplikasi ini dilakukan melalui pengambilan angket/ responden dengan Rumus Slovin yaitu, $\mathrm{n}=$ $\mathrm{N} / \mathrm{N}(d)^{2}+1$ dimana $\mathrm{n}=$ sampel, $\mathrm{N}=$ populasi, $\mathrm{d}=$ persentase kesalahan (penulis mengambil nilai 24,5\%) didesimalkan menjadi 0.245. Dari jumlah populasi 38 siswa IPA, maka jika di masukan di dalam Rumus Slovin adalah sebagai berikut:

$$
\begin{aligned}
& =38 / 38(0,245)^{2}+1 \\
& =38 / 38 *(0,060025)+1 \\
& =38 / 2,28095+1=17,6597
\end{aligned}
$$

sehingga dibulatkan menjadi 18, jadi responden yang dibutuhkan dari 38 total siswa kelas 10 (IPA) adalah 18 siswa. responden ini menggunakan media google from kemudian link nya di share menggunakan media online (whatshap). Untuk memastikan hasil dari aplikasi ini, penulis menampilkan aplikasi pembelajaran larutan elektrolit dan non-elektrolit berbasis android. Dapat disimpulkan hasil dari responden ini penulis menilai melalui grafik penilaian. Ada beberapa penilaian yang akan dipilih responden, seperti Sangat Setuju (SS), Setuju (S), Tidak Setuju (TS), dan Sangat Tidak Setuju (STS). Seperti pada gambar berikut ini.

\section{Gambar 23}

Presentasi Penilaian

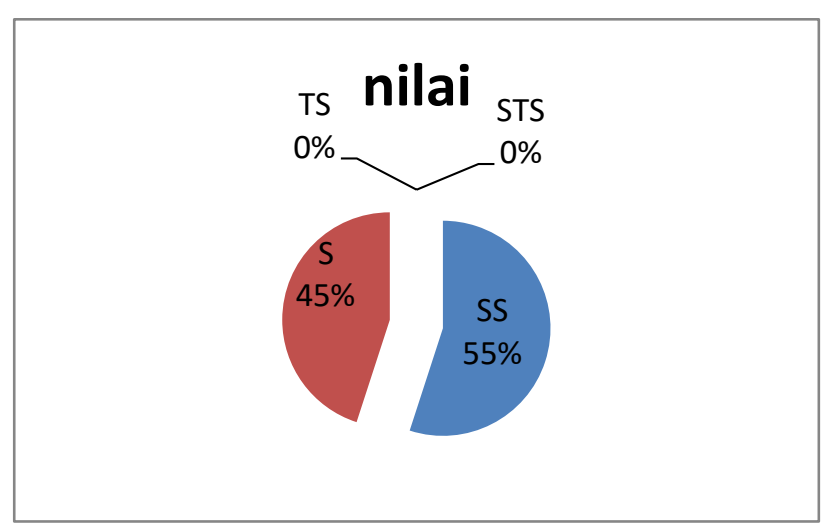

Berdasarkan grafik persentasi penilaian media pembelajaran larutan elektrolit dan non-elektrolit berbasis android dengan rumus mencari pesen adalah $\rho=\mathrm{f} / \mathrm{n} * 100$ dimana $(\rho$ $=$ persentase $\mathrm{f}=$ frekuensi dari setiap angket dan $\mathrm{n}=$ jumlah responden) Sehingga dapat kesimpulan bahwa keseluruhan penilaian dari 18 responden yang menyatakan Sangat Setuju ada 99 dari jawaban pada kuesioner, sehingga jika dimasukkan didalam rumus persentase yang didapatkan dari perhitungan adalah $55 \%$, yang menyatakan Sangat setuju, dan ada $45 \%$, yang menyatakan setuju dari 81 jawaban kuesioner, tidak setuju ada $0 \%$, dan yang menyatakan Sangat Tidak Setuju ada $0 \%$.

\section{a) Hasil Wawancara Dan Observasi}

Pada tahapan wawancara dengan pakar/guru kimia, tidak dapat penulis lakukan dikarenakan ketika penulis melakukan penelitian ini dunia tengah mengalami pandemic virus Covid-19 atau 
(Corona Virus Disease-19), sehingga menyebabkan hampir semua sekolah ditutup dan semua siswa belajar online termasuk di lokasi penelitian penulis sehingga penulis tidak dapat melakukan wawancara dan observasi ditempat lokasi, penulis memutuskan untuk mengganti wawancara dengan mengambil semua pembahasan materi larutan elektrolit dan non-elektroit dari buku kimia yang diajarkan di sekolah yang sesuai standar kurikulum yang ditetapkan oleh pemerintah tampa wawancara dengan pakar/guru kimia. Sehingga penulis melakukan wawancara untuk meminta tanggapan tetang aplikasi yang telah penulis buat kepada beberapa siswa SMA Negeri 05 Tapung menggunakan google from.

\section{KESIMPULAN}

Setelah dilakukan analisis dan perancangan sistem, serta implementasi dan pengujian pada rancang bangun aplikasi media pembelajaran larutan elektrolit dan non-elektrolit dari kimia dasar berbasis android, dan mengacu pada hasil akhir penelitian, dapat disimpulkan bahwa: (1) Membangun sebuah aplikasi media pembelajaran larutan elektrolit dan nonelektrolit berbasis android. Sehingga aplikasi ini dapat digunakan sebagai metode pembelajaran siswa, dengan ada nya aplikasi ini, menjadikan siswa lebih mudah mengerti dan memahami materi pembelajaran larutan elektrolit dan non-elektrolit, pembuatan aplikasi ini menggunakan Adobe Flash CS6 dan bahasa pemograman Action Script 3.0.; (2) Aplikasi media pembelajaran larutan elektrolit dan non-elektrolit berbasis android, telah diuji dengan menggunakan metode pengujian Black Box Testing, menunjukkan hasil yang bagus. Dengan tampilan yang menarik dan menyenangkan terbukti dari hasil respon siswa yang diperoleh menggunakan angket google from pada siswa, menunjukkan hasil yang baik dengan presentase hasil rating $55 \%$ sangat setuju dan
$45 \%$ setuju. Dengan begitu, media pembelajaran ini dapat meningkatkan motivasi belajar siswa siswa dan juga dapat digunakan sebagai alat bantu guru dalam memberikan pejelasan tentang materi dan pratikum dalam mata pelajaran kimia terutama pada pembelajaran tentang larutan elektrolit dan non-elektrolit, sehingga dapat digunakan sebagai alat bantu guru dalam menyampaikan materi kepada siswa. Oleh karena itu, aplikasi media pembelajaran larutan elektrolit dan non-elektrolit ini masih perlu dikembangkan kembali untuk animasi, serta materi dan tampilan yang lebih menarik serta kompleksitas dalam variasi komponennya serta dapat dikembangkan untuk materi mata pelajaran yang lainnya.

\section{REFERENSI}

Adami, F. Z., \& Budihatanti, C. (2016). Penerapan Teknologi Augmented Reality Pada Media Pembelajaran Sistem Pencernaan Berbasis Android. Jurnal Teknik Komputer AMIK BSI, 2(1), 122-131.

Bentelu, A. S., Sentinuwo, S., \& Lantang. O. (2016). Animasi 3 Dimensi Pencegahan Cyber Crime (Studi Kasus: Kota Manado). Journal Teknik Informatika, $8(1)$.

Clara. (2017). Pengembangan Multimedia Interaktif Menggunakan Adobe Flash Cs3 untuk Pembelajaran Sistem Pencernaan di SMP. Skripsi, Pendidikan Biologi Fakultas Keguruan dan Ilmu Pendidikan Universitas Pasundan Bandung. Dwinata, R. A., Efendi, R., \& Yudha S, S. P. (2016). Rancang Bangun Aplikasi Tabel Periodik Unsur dan Perumusan Senyawa Kimia dari Unsur Kimia Dasar Berbasis Android. Jurnal Rekursif, 4(2).

Fatmawati, S. (2015). Pengembangan Mobile Learning Berbasis Android Menggunakan Adobe Flash Cs6 Pada Mata Pelajaran Bahasa Inggris Untuk 
Meningkatkan Hasil Belajar Siswa

Kelas X TKJ SMK Hidayah Semarang.

Tesis, Fakultas Ilmu Pendidikan Universitas

Negeri Semarang.

Khuzaini, N., Sulistyo, T.Y. (2020).

Pengembangan Media Pembelajaran

Interaktif Berbasis Android

Menggunakan Adobe Flash Cs6 Pada

Materi Segiempat dan Segitiga.

Prosiding Konferensi Pendidikan Nasional,

2(1).

Maisyaroh, Mulyani, A., \& Juanda, A.

(2017). Rancang Bangun Aplikasi

Pembelajaran Tabel Periodik Unsur

Kimia Berbasis Android. Jurnal

Bianglala Informatika, 5(2).

Sabrinatami, Z, \& Rinawati, Wika (2018).

Pengembangan Media Pembelajaran

Video Animasi Stop Motion Pembuatan

Kue Dari Tepung Beras Pada Mata

Pelajaran Kue Indonesia Di SMK N 4

Yogyakarta. Jurnal Pendidikan Teknik

Boga, 7(3).

Saurina, N. (2017). Game Edukasi Sebagai Media Pembelajaran untuk Kelas IV SDN Banjarsugihan II Menggunakan Blender 3D. Jurnal Sistem \& Teknologi Informasi Indonesia, 2(2).

Solihah, Mar'attus., Yektyastusi, Resti., Prasetyo, Yogo D. (2015)

Pengembangan Media Pembelajaran Kimia Berbasis Android Sebagai Suplemen Materi Asam Basa Berdasarkan Kurikulum 2013. Prosiding Seminar Nasional Pendidikan Sains (SNPS).

Syarifudin, M. K. (2017). Pengembangan Aplikasi Mobile Learning

Menggunakan Adobe Flash Cs6 Sebagai Penunjang Pembelajaran Fisika Pada Materi Hukum Newton Untuk Siswa SMA/MA Kelas X. Tesis, Fakultas Sains Dan Teknologi Universitas Islam Negeri Walisongo Semarang.

Tim Masmedia Buana Pustaka. (2017). Kimia
Peminatan Matematika Dan Ilmu Alam. Jakarta: PT Masmedia Buana Pustaka (SL).

Untuk SMA/MA Kelas $X$ Kelompok 